\title{
AN EVALUATION OF GEOGRAPHY TEACHERS' COMPETENCES VERSUS TEACHING EXPERIENCE
}

\author{
Wiktor Osuch
}

\begin{abstract}
Changes which took place in the last years within the European higher educational system, necessitated special attention to the effects of the Bologna Declaration influence on the process of training of future teachers in Poland. The author of this paper believes that the acquisition of the appropriate competences by geography students - candidates for teachers constitutes the most important element in professional training of the future teacher including a geography teacher. The aim of the performed research was: a comprehensive assessment of the acquisition of competences by geography teachers - mentors of vocational teacher trainings, a multifaceted analysis of factors influencing the process of developing students' competences - candidates for geography teachers and also working out a model of the assessment of teachers' competences by geography students. The presented research is an attempt to find the relationship between the received points given for the development of competences and the assessment performed both in points and marks given by geography students who did vocational teaching training with geography teachers as their mentors at school. Students assessed the observed lessons which were carried out by geography teachers - their mentors.
\end{abstract}

\section{Key words}

Polish geography teacher, subject and didactical competences, questionnaire survey and correlations of assessments, teaching experience.

\section{Introduction}

After many attempts to reform Polish educational system, beginning with the change of types of schools, levels of education, syllabuses for each subject, curricula, textbooks, aims and content of subject teaching, very little has been done to shape a contemporary teacher, the teacher of the $21^{\text {st }}$ century.

In the process of training of future teachers, including geography teachers, competences acquired mainly during geography studies and vocational 
training at school play the vital role. This report presents research results and a discussion concerning subject and teaching competences of geography teachers and candidates for this profession described in monograph (Osuch 2010). In the quoted monograph the author focuses on the assessment of the acquisition of specific competences by teachers (teachers' self-assessment of their competences) and the assessment of these competences by students. The analysis and assessment of the process of geography teachers' training in Poland constitute the considerable part of monograph.

The presented article discusses, first of all, the results of the research on the correlation between geography teachers' work experience and the extent to which they acquired various competences

The aim of the performed research was the self-assessment of the acquired subject and teaching competences by geography teachers in gimnazjum ${ }^{1}$ and liceum ${ }^{2}$, and bachelor (BA) and master (MA) students of geography. The obtained results in this part of the research are shown in Figure 1.

Another aim of the research was the assessment of the selected teaching competences by geography teachers. BA and MA students of geography assessed teaching competences of their mentors during observations during their teaching training. The obtained results of the assessed competences were compared with work experience of those mentors. The results of this part of research are shown in the chapter discussing research results - the correlation between the acquired competences and work experience of a teacher.

Having obtained interesting results of the research, the author of this paper made an attempt to examine the relationship between the number of the received points in the scope of the development of competences and the marks both in points and grades given by geography students who did the teacher training with those teachers as their mentors. Students assessed lessons which they observed. In addition, teaching experience of teachers was taken into account and it was correlated with both the assessment performed by teachers who were the mentors as well as their trainee geography teachers.

1 Gimnazjum - a three-year obligatory, comprehensive school, attended by students from 13 to16 years of age (lower secondary school).

2 Liceum - a three-year comprehensive school with classes with specialisation, attended by students from 16 to 19 years of age. Students finish school with so called 'matura' exam, the equivalent of A-level exams which is required to enter a university (upper secondary school). 


\section{Methods of research}

Method of diagnostic survey, known also as a questionnaire method was used to examine the teaching competences. The questionnaire form which included closed single and multiple choice questions was used as the research tool. Survey was carried out among both geography teachers - mentors and geography students. The survey was conducted among 96 geography teachers (in years 2008 and 2009), graduates in teaching faculty of geography studies department at Pedagogical University of Cracow (previously known as Pedagogical Academy), Jagiellonian University and also, in individual cases, graduates from University of Silesia in Katowice, Nicolaus Copernicus University in Torun and Maria Curie Skłodowska University in Lublin. In addition, for comparative purposes, 136 geography students from three different faculties of studies at Pedagogical University of Cracow took part in the survey.

Distribution $\mathrm{t}$ of a Student with $\mathrm{n}-2$ degrees of freedom was used to calculate the correlation between the examined variables and also the observed value of the coefficient of the linear correlation $r$ was compared with the critical value $r_{\alpha}$ calculated by means of a formula. Free computer program Mathematica 5.2 (for student) Wolframa was used to calculate the correlation.

The linear correlation was calculated from the following formula:

$$
r=\frac{\sum_{i=1}^{n}\left(x_{i}-\bar{x}\right)\left(y_{i}-\bar{y}\right)}{\sqrt{\sum_{i=1}^{n}\left(x_{i}-\bar{x}\right)^{2} \sum_{i=1}^{n}\left(y_{i}-\bar{y}\right)^{2}}} .
$$

Conclusion was inferred by means of the following statistic

$$
t=\frac{r}{\sqrt{1-r^{2}}} \sqrt{n-2} \text {. }
$$

This statistic has the distribution $t$ of a Student with $n-2$ degrees of freedom, with the assumption that the hypothesis $\mathrm{H}_{0}(\mathrm{r}=0)$ is correct. In tables of distribution $t$ of a Student for the set in advance level of significance $\alpha$ 
and for $\mathrm{n}-2$ degrees of freedom we read the critical value $\mathrm{t}_{\alpha}$. This number meets the condition $P\left\{|t| \geq t_{\alpha}\right\}=\alpha$.

We assume, as it is often done in didactic research, the level of significance $\alpha=0,05$.

It is known from the theory that when after comparing the calculated value $t$ with the critical value $t_{\alpha}$ we obtain the inequality $|t| \geq t_{\alpha}$, then the hypothesis $\mathrm{H}_{0}$ about the lack of correlation between the variables needs to be rejected. The conclusion is inferred as follows:

If the observed value $t$ satisfies the inequality $|t| \geq t_{\alpha}$ then the zero hypothesis $\mathrm{H}_{0}$ is rejected in the favour of alternative hypothesis which says that the correlation coefficient doesn't equal zero. However, when $|t|<t_{\alpha}$ there is no grounds for rejecting the hypothesis $\mathrm{H}_{0}$ that variables are not correlated.

\section{Literature review}

The profession of a teacher in the past and, contrary to some negative opinions of some people, currently has in general quite high public recognition. Its relatively high position among other professions results from the tasks performed by a teacher. Society expects that people who become teachers should be special, taking into account both professional qualifications and moral principles. Teachers should be able to reach a specific social rank, to be an authority for students, parents and local environment (Żegnałek 2007).

It is true that many educationalists and teaching and learning experts think that indeed one can learn the skills needed for teaching profession, especially those which are directly connected with the ability to share knowledge and develop some skills of students but is it sufficient to perform educational tasks well and perform duties of a teacher and a tutor conscientiously? Is the acquisition of certain knowledge and skills a sufficient condition to be a good teacher? These questions bother many educationalist and teaching and learning experts (Żegnałek 2007).

The characteristic feature of the teaching profession is work with "human beings who differ from each other, who are characteristic for themselves and who require an individual approach' (Miszczuk 2007, p. 43). Teacher has a role of an obliging adviser, initiator and organizer. According to R. Perry (2000) a teacher at work should present 'the ability to prepare and organize activities and experiences in such a way that they trigger the process of children's learning and thinking in the appropriate moment' (Perry 2000, p. 105). 
Currently, instead of a discussion on selected personal features of candidates for teachers more and more often the notion of competences is used in literature. These competences should be acquired by a student of teaching faculty - a candidate for a teacher, including a geography teacher.

S. Piskorz (1996) writes extensively about a geography teacher, defining him or her as 'a person who identifies himself or herself with the profession of a teacher, and a teacher's speciality should be regarded in terms of the acquired profession and actual profession. An acquired profession means university studies including teaching and psychological preparation; an actual profession is the complete or incomplete teaching of geography at school' (Piskorz 1996, p. 144). S. Piskorz (1996, p. 144) defines the complete teaching of geography as 'the effective dissemination of geographical knowledge, developing various factual and formal skills and getting accustomed to the specific system of values and developing the appropriate attitudes by a person with the adequate preparation to do that' (university studies). A geography teacher from a classical perspective is a person who is energetic, enterprising, good organizer who knows the local environment very well and who works for the local community in which he or she lives. He or she is a cheerful person and even with a sense of humour. Geography teacher's character features are: cordial, just, understanding, firm, orderly, leader, a person with vivid imagination and ability to act evocatively and also to be a well-mannered person. (Piskorz 1997).

A Czech geographer and educationalist A. Wahla (2000) wrote about the qualifications of future geographers and the necessity to use various sources of knowledge by geographers (of economics, engineering, technology and politics) as well as to set the whole process of education in the aspect of profound social and economic transformations in the world.

A Slovak geographer and educationalist J. Kancir (2000) described the old, contemporary and future projects of geography textbooks as they are perceived by geography teachers. In addition J. Kancir created the criteria of textbook assessment and carried out exemplary analyses and assessment of those textbooks. In his next publication J. Kancir (2004) discussed the subject of a detailed didactics in the aspect of questionnaire surveys of students. J. Kancir made a number of remarks, mainly in the form of postulates concerning further education at geography faculty and training of the future teachers of geography. 
An Austrian specialist on geography didactics G. Atschko (2004) brought up the subject of preparation of geography teachers for new forms of educational activity at school. Another Austrian geography didactics specialist Ch. Fridrich (2004) presented a theoretical model of teaching geography and economic subjects at school in the aspect of standards of teaching and assumptions resulting from curricula.

Currently, there are many various definitions of competences from the perspective of teaching profession. Pedagogues, didactics specialists and pedeutology specialists claim that it is difficult to describe a competence with an unambiguous definition.

The latest publications describe competences as all kinds of knowledge, skills, talents, virtues, experiences and social forms of authorizations, which are regarded by an individual as the sufficient ground for free, subjective activity - effective or even creative (Hartman 2007).

The division of professional competences of teachers performed by Ch. Kyriacou (1991) inspired other authors to carry out further research concerning teachers' competences. Ch. Kyriacou divided the competences into: specialist competences (those connected with a subject), psychological and teaching competences, communicative, organizational and managerial, diagnostic and interventional, competences connected with the reflection on teachers' own activities.

F. A. J. Korthagen i T. Wubbels (1995) described in detail the process of experience acquisition and the process of becoming an expert in teaching profession.

Ch. Day (2004) in the publication Professional development of a teacher presented the dynamics of career in teaching profession. It is a peculiar study of the reflection on school culture and the management of the quality of teacher training and development. In another publication Ch. Day (2008) tries to prove that school is the environment for intellectual challenges, also for a teacher, and teaching profession, which requires energy, involvement and determination, is for brave people. Ch. Day gives tips how to teach with passion, keep enthusiasm and how to find time for reflection and not to get discouraged from teaching career. 
Czech pedeutologist J. Průcha (2006, p. 306) defines teacher's competences as 'a set of professional skills, knowledge, values and approaches which every teacher should possess in order to perform their job effectively. J. Průcha (2006) indicates the following elements of teacher's competences model:

- 'planning and preparing a lesson (aims of a lesson),

- performing the lesson,

- managing the lesson (keeping students' active involvement strong),

- the atmosphere during the lesson (creating positive approaches among students and motivating them to participate in a lesson),

- discipline (keeping order during the lesson),

- assessment of students' achievements (assessment of achievements mainly in order to help students in their personal development),

- reflection on teachers' own work and evaluation' (J. Průcha 2006, p. 308).

Ch. Vielhaber (2006) wrote about the classification of competences and the profile of a geography graduate of University of Vienna. Interestingly enough, $\mathrm{Ch}$. Vielhaber gives little attention to competences connected with the subject of geography. He emphasises the competences in cooperation, motivation to take action, plan, reflection on one's own actions, introduction of innovations. Such a division of competences puts stronger emphasis on soft competences which are nowadays more and more often analysed and described (Osiński 2010, Osuch 2011).

H. De Jong (2008) wrote about training of geography students - candidates for teachers in the Netherlands. Apart from the analysis of syllabuses of geographers' training and teaching practice at school H. De Jong described the profile of graduates and their competences. He divided competences into: communicative, pedagogical, specialist, teaching, organizational, in the scope of cooperation with teachers, parents and in the scope of reflection and professional development. Curiously enough, competences concerning the subject of geography are not emphasised separately but discussed together with teaching competences.

Ch. Vielhaber in his next publication (2008) expressed his point of view in the discussion on standards of geography students' training and competences invoking definitions of other authors, for example J. Erpenbeck's and L. Rosenstiel's (2003) and modifying them. It was the introduction to the 
discussion on the subject of relationship between standards and competences, what students of geography should know and what they must know.

D. Lambert (2008) in his article presenting the theoretical discussion and assumptions of the future school geography taught in high schools. He wrote on curricula, students' competences, about the necessity to continue geography education after reaching the age of 14 , about the great 'potential' of geography and the need to use it, despite the criticism of this subject in the British mass media which described the subject as 'taught in a boring way'.

E. Hofmann (2009) presented the position of geography as the subject taught at Czech schools, referring to the rank of geography didactics. E. Hofmann invokes the textbook written by D. Lambert and D. Balderstoune (2000), which became the inspiration for the English and American school of teaching geography. He stirs up a discussion on the possibilities of development of geography didactics. Matters discussed by E. Hofmann seem to be relevant today and needed because school geography and geography didactics are in regression in Poland, Czech Republic and Slovakia.

In recent years, especially in the countries of western Europe, research concerning later professional fate of university graduates, including geography faculty graduates, is performed. The research concerns the relationship between the employers' demands for specific competences of university graduates, quality of students' education and the situation on the job market. For example, research concerning the demand for specific competences was carried out as a result of university geography education among employees on a European scale (Donert, Charzyński, Podgórski 2007). This research shows different directions of the approach to studies and professional work. For instance, studies for passion (this is an ideal situation) and the equipment with numerous factual and formal competences constitutes the sufficient input of university into preparation of a graduate for the job market. Employability is not treated as the aim of studying, as this is the job of vocational schools, but one of its effects and this is the task that graduates equipped with a set of competences should deal with on their own (Heron, Le Hathaway - 2000, Owen 2001). High interest of employers in graduates of geography, ecology and geology faculties owing to the research being performed, is also the result of preventing unemployment among graduates (Gedye, Fender, Chalkley 2004 and Maguire, Guyer - 2004). 
D. Piróg (2010) reviewed the research on education and job market, the research on later professional fate of graduates, the quality level of university education paying special attention to the job market and the research concerning employers' requirements which graduates - candidates for work need to meet. Unfortunately, in Poland such research hasn't been performed on a wider scale, although one may expect that soon, also among geographers of different specialities, such research will be carried out.

The presented above review of literature does not exhaust the subject of widely understood professional training of geography teachers. It gives only the theoretical basis for further discussion and analyses concerning the development of competences.

\section{Research results - competences of geography teachers and students - candi- dates for teachers}

Maximum 415 points could be received in the questionnaire concerning teaching and factual competences of geography teachers (and also geography students - candidates for teachers). The questionnaire consists of four parts whose each refers to a different group of competences. Part I concerns the factual competences in the field of geography. Each respondent could receive maximum 200 points. Part II refers to teaching competences in geography didactics. Each respondent could receive maximum 100 points. Part III is about teaching competences in protective and educational pedagogy. Each respondent could receive maximum 70 points. Part IV concerns competences in the knowledge of educational law. Each respondent could receive maximum 45 points (Osuch 2010).

Detailed results of the self-assessment of the acquired competences by both teachers and geography students - candidates for teachers are presented on the chart (Fig. 1).

The results of the research on the acquired competences are diversified in each group.

On the basis of the obtained results it must be stated that teachers of various subjects, doing postgraduate studies in geography demonstrated significantly worse competences than active geography teachers. The score is as much as 80 points worse. In this examined group of people both very positive examples of developing competences and negative examples were observed. The negative examples aroused many doubts or even controversy over the 
Fig. 1

Competences acquired by teachers and geography students in point scale.

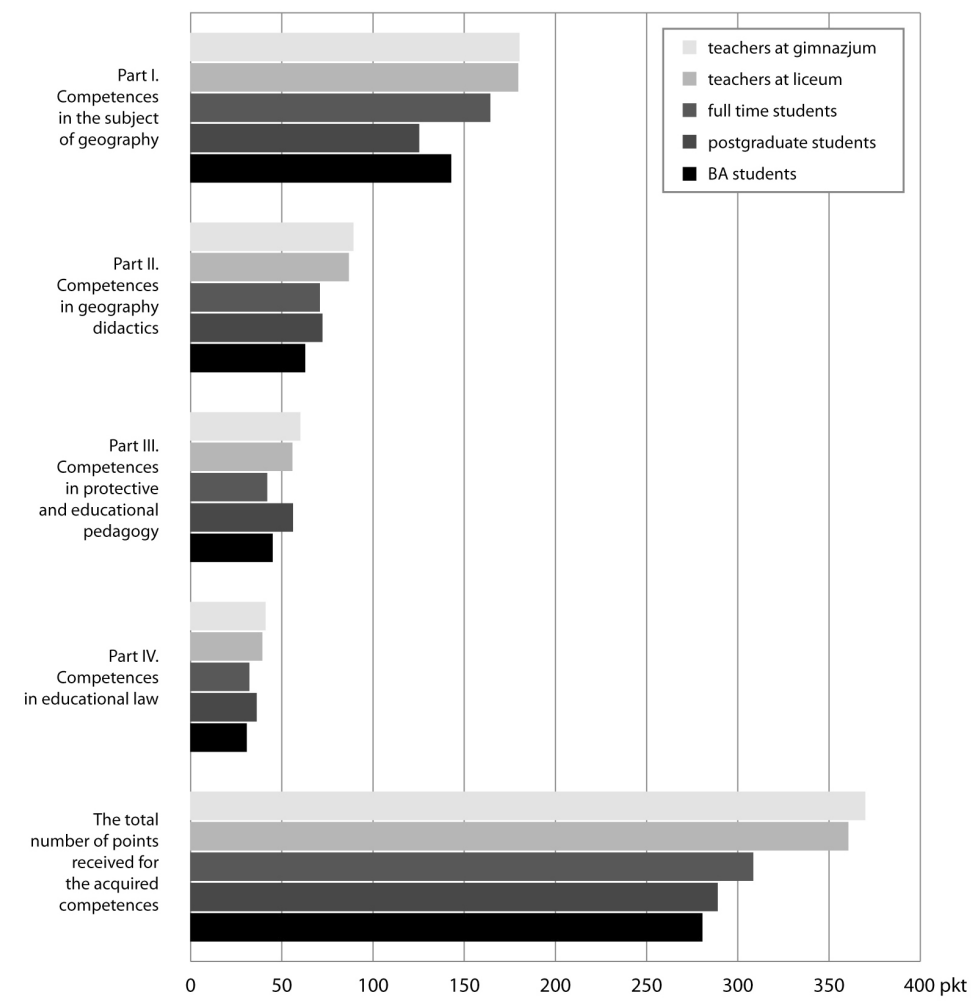

Source: Osuch W. (2010, p. 167) - Fig. 69

suitability of those people to become teachers. Teacher with more experience and at the higher level of professional advancement developed competences to a significantly larger extent than teacher with less experience and at the 
lower level of professional advancement, which can be easily noticed in the results obtained in part IV, III and II of the set of competences. Especially the results obtained in these parts of competences may reflect the work experience of a teacher.

The results obtained by full time geography students in the scope of development of competences are a few or a dozen or so points lower for each analysed set of competences in comparison with active geography teachers in gimnazjum and liceum. This difference in points is about 72 points in relation to the total amount of points received.

Geography students received less points especially in part II, III and IV of the set of competences as they lack experience in developing competences particularly teaching competences which are also (especially) developed and practised during practical lessons at school during a longer period of gaining teaching experience. Vocational teacher training at both gimnazjum and liceum is too short to develop, practise and verify the acquired experience. Teaching competences in geography didactics were less developed by MA students (about 13 points less). The results obtained by these group of students in part II and IV of the set of competences were similar to those obtained by postgraduate students. This results from the work experience of active teachers who reach the consecutive levels of professional advancement.

Results concerning the acquired competences among part time BA students are more levelled and less diversified than the results obtained by MA students. The fact that the results obtained by part time BA students are less diversified may be caused by the fact that there was a small number of the analysed questionnaires (36) and that students were highly motivated to prepare themselves for the role of a geography teacher.

\section{Research results - the correlations between the assessment of the acquired competences and work experience of teachers}

In the next part of the research geography teachers' competences were assessed during their lessons at school. The assessment was performed by geography students doing vocational teaching training. Students used a questionnaire survey. The author of this paper had detailed results of geography teachers' surveys and also additional information concerning teaching experience of those teachers at school. In this case data concerning teaching experience of each geography teacher and assessment performed by students doing vocational teaching training were used. 
At the beginning of the research a hypothesis was formed that the assessment of geography teachers' competences performed by geography students during observations depends on the teaching experience of those geography teachers.

Correlations were calculated for five groups of teachers:

a) teachers at gimnazjum - mentors of part time geography students,

b) teacher at post - gimnazjum schools (most frequently at liceum) - mentors of full time geography students,

c) teachers at gimnazjum - mentors of full time geography students,

d) teacher at gimnazjum and liceum - mentors of full time geography students $(\operatorname{sum} b+c)$

e) all teachers - mentors of vocational teaching training (sum $a+b+c)$.

Re a) Correlation $r=0.21$ was calculated with the critical value $r_{\alpha}=0.20$, which means that there is a correlation (significant correlation) between the teaching experience of teachers - mentors of vocational teaching training of part time students at gimnazjum and the assessment of teachers' competences performed by geography students during observations. Positive correlation means that the longer the teaching experience of a geography teacher is, the better mark they received for their lessons from geography students. The obtained result may prove both that there is a regularity that an experienced teacher with a longer teaching experience and at the higher level of professional advancement is able to give effective lessons and also very good lessons in the opinion of geography students. In addition, teachers - mentors in small towns cooperate with universities more seldom than teachers in cities, e.g. in Cracow and are much better prepared for the lessons which were observed by geography students.

Re b) Correlation $\mathrm{r}=-0.31$ was calculated with the critical value $r_{\alpha}=0.18$, which means that there is a significant correlation between teaching experience of teachers - mentors of vocational teacher training of full time students in liceum and the assessment of teachers' competences carried out by students while observations. Moreover, the negative correlation means that the longer teaching experience of teachers at school (in liceum) is, the lower mark was given to those teachers from students who observed their lessons. The obtained score is highly surprising and can be interpreted in various 
ways. Among other things, teachers with longer teaching experience and often older teachers fall into a routine during lessons. Such teachers' lessons are not interesting in liceum. They do not use diversified teaching methods and often give a lecture during their lesson which is an effective way to cover the material and prepare students for their matura exams (equivalent of A-levels). More experienced teachers often cover the material quickly without any moments to give some thoughts to the material, to discuss it with students or reflect on it. Teacher at schools in big cities (e.g. in Cracow), who are preoccupied with the abundance of duties and tasks, do not give too much attention to looking after students during teaching training. Also students themselves would like to have as their mentors in liceum teachers who are ambitious and active, often with less teaching experience and younger but not conservative teachers who do not fit in the modern world and school's tasks. MA students are demanding towards their teachers-mentors while vocational teaching training at liceum, where teaching experience of their mentors, their age, and the level of professional advancement is significant for the assessment of their competences during observations and thus the whole teaching experience of these teachers-mentors.

Re c) Correlation $r=-0.18$ was calculated with the critical value $r_{\alpha}=0.14$, which means that there is a significant correlation between teaching experience of teachers - mentors of vocational teacher training of MA students in gimnazjum and the assessment of teachers' competences during geography lessons carried out by students while observations. Teaching experience of teachers at gimnazjum influenced significantly the assessment of competences performed by full time students doing their first teaching training. It means that both older teachers and those with longer teaching experience were assessed by geography students as well as younger teachers and those with shorter teaching experience. Moreover, it must be stated that, above all, young teachers with short teaching experience were exceptionally highly assessed by students (hence the negative correlation). MA students undergoing their vocational teaching training at gimnazjum also proved to be strict for their mentors (similarly to lyceum, see item $b$ above).

Re d) Correlation $\mathrm{r}=-0.20$ was calculated with the critical value $r_{\alpha}=0.11$, which means that there is a significant correlation between teaching experience of teachers - mentors of vocational teacher training of full time students in gimnazjum and liceum ( $\operatorname{sum} b+c)$ and the assessment of teachers' com- 
petences during geography lessons carried out by students while observations. In addition, negative correlation means that the longer the teaching experience of a teacher at school (at gimnazjum and liceum) is, the lower mark in competences that teacher received from observing them students. Certainly, the result was influenced by the analysed separately example of MA students' teaching training at lyceum (see item $b$ above) but also some examples of lessons assessed by MA students in gimnazjum. Moreover, it must be emphasised that full time students had high requirements towards their mentors not only at liceum but also at some gimnazjums, especially in big cities. Routine of some teachers was probably also taken into account during the assessment.

Re e) Correlation $\mathrm{r}=-0.09$ was calculated with the critical value $r_{\alpha}=0.09$, which means that there is a correlation possible (a negative one) between teaching experience of teachers - mentors of vocational teacher training of all students (sum $\mathrm{a}+\mathrm{b}+\mathrm{c}$ ) and the assessment of teachers' competences during geography lessons carried out by those students while observations. When all analysed groups of students are summarised, it must be stated that the longer the teaching experience of teachers at school (both at gimnazjum and liceum) is, the lower the mark for their competences was given by the observing them students (negative correlation). Such results surprised the author of this paper, as he had not expected a negative correlation for the total of all analysed cases.

As it was mentioned before, among the group of geography teachers mentors of students' vocational teacher training, information about teaching experience was included in the questionnaire as well as marks in points for the acquired competences. It was decided that it had to be examined whether there was a relationship between the teaching experience of geography teachers and the total amount of all points given for the acquired teaching and subject competences (on the basis of self-assessment of teachers). Correlation $\mathrm{r}=0.35$ was calculated with the critical value $r_{\alpha}=0.27$, which means that there is a significant correlation between teaching experience of teachers and selfassessment of those teachers concerning the total amount of points given for each acquired competence. Correlation for the group of all geography teachers taking part in the survey was calculated. In this particular case it can be concluded that the longer the teaching experience is, the more competences geography teacher acquired. However, it must be taken into consideration 
that teachers themselves assessed acquisition of their own competences and certainly, more experienced teacher were more confident about their skills and competences. Novice teachers with short teaching experience might have been careful with their self-assessment of their competences and thus their achievements in acquisition of teaching and subject competences were lower. Attention must be drawn to the connection between teachers' teaching experience and students' assessment of teachers' competences in performing a specific lesson during vocational teacher training. In this case a negative correlation was obtained in groups of teachers at gimnazjum and liceum and in the assessment performed by full time students, which means that the longer teaching experience of geography teachers at school was, the poorer the assessment of their competences in performing a lesson was.

\section{Conclusion and generalisations}

It is difficult to state explicitly, which teachers-mentors score highly in the assessment of geography students - candidates for teachers. Taking into account teachers' longer work experience at school, higher level of professional advancement, well developed competences one may assume that such teachers should also receive high marks from students doing vocational teaching training at school. However, teachers with long teaching experience do not necessarily get the highest marks from students, both in points concerning specific competences and in a general assessment of lessons.

Reasons can be different:

- in spite of the prepared observation template, the assessment of a lesson by students is subjective. It must be underlined that for geography students doing vocational teacher training at a post gimnazjum school usually at liceum it is their second teaching training and they often already have a worked-out conception of a lesson and work with young people,

- possibility of conflicts during vocational teacher training between students and their mentors. It creates favourable conditions for stricter assessment of mentors by their students and also a lower mark in teaching practice (there were such cases, especially among teachers-mentors with long teaching experience and a significant age difference between students and their mentors),

- presented by teachers-mentors often incomprehensible approach towards young people, changes in economic and political life, imposing 
one's opinion, creates favourable conditions for conflicts and stricter assessment of students for mentors' prestige (there were also such single cases, especially during teacher training in post-gimnazjum school among older geography teachers-mentors with longer teaching experience).

\section{References}

1. ATSCHKO, G. Geographie und Wirtschaftskunde (Österreich): ein Fach eine Antwort? In Osuch W., Piróg D. (eds.): Ksztatcenie i dokształcanie nauczycieli geografii w Polsce $i$ w krajach Unii Europejskiej $w$ drodze do jednoczacej się Europy. Wyd. Naukowe Akademii Pedagogicznej, Kraków 2004, pp. 112-125. ISBN 83-7271-268-9.

2. DAY, CH. Rozwój zawodowy nauczyciela (trans. by Joanna Michalak). Gdańskie Wydawnictwo Psychologiczne, Gdańsk 2004, p. 334. ISBN 83-89120-95-x.

3. DAY, CH. Nauczyciel z pasją. Jak zachować entuzjazm i zaangażowanie w pracy (trans. by Tomasz Kościuczuk). Gdańskie Wydawnictwo Psychologiczne, Gdańsk 2008, p. 224. ISBN 978-83-7489-137-0.

4. DE JONG, H. Aspekte der Ausbildung von Geographielehrer/inne/n In den Niederlanden. GW Unterricht Nr 109/2008, Wien, pp. 27-32. ISSN 20771517.

5. DONERT, K. - CHARZYŃSKI, P. - PODGÓRSKI, Z. (eds.) Teaching Geography in and about Europe. Toruń 2007, Herodot Network, p. 143. ISBN 978-083-7352151-3.

6. ERPENBECK, J. - ROSENSTIEL, L. (eds.) Handbuch Kompetenzmessung> Stuttgart: Schäffer-Poeschl 2003, 641 p.

7. FRIDRICH, CH. Geography and Economic Sciences' in Austrian schools and the importance of project learning. In Osuch W., Piróg D. (eds.): Ksztatcenie i doksztatcanie nauczycieli geografii w Polsce $i$ w krajach Unii Europejskiej w drodze do jednoczacej się Europy. Wyd. Naukowe Akademii Pedagogicznej, Kraków 2004, pp. 131-153. ISBN 83-7271-268-9.

8. GEDYE, S. - FENDER, E. - CHALKLEY B. Geography and Jobs: Undergraduate Expectations and Graduate Experience. Journal of Geography in Higher Education, 28/2004, nr. 3, pp. 381-396. ISSN 1466-1845.

9. HARTMAN, J. Przez filozofię. Ureus Kraków 2007, 557 pp. ISBN 978-83-60741-00-9.

10. HERON, R. - LE HATHAWAY, J. T. An International Perspective on Developing Skills through Geography Programmes for Employability and 
Life: Narratives from New Zeland and the United States, Journal of geography Higher Education, 24/2000, nr. 2, pp. 271-276. ISSN 1466-1845.

11. HOFMANN, E. Didaktika geografie aneb „vůz se čtyřmi koly nebo páté kolo u vozu?". GEODAYS LIBEREC 2008. Book of proceedings. Annual International Geographical Conference of the Czech Geographical Society, Liberec August 25-29 ${ }^{\text {th }}$, 2008. Technical University of Liberec, Liberec 2009, pp. 230-235. ISBN 978-80-7372-443-6.

12. KANCIR, J. Učebnice geografie včera, dnes a zajtra očami učitel'ov. Učebnice geografie 90. let. Sborník referátů z mezinárodní konference konané 18-19. 4. 2000 v Ostravě. Ostravská univerzita, Přírodovědecká fakulta Ostrava 2000, pp. 52-62. ISBN 80-7042-798-1.

13. KANCIR, J. Odborové a predmetové didaktiky - ich zameranie a úlohy v súčasnosti. Geografie a proměny poznání geografické reality. Sborník př́íspěvků z Mezinárodní konference konané ve dnech 30. a 31. 8. 2004 v Ostravě. Ostravská univerzita, Př́rodovědecká fakulta Ostrava 2004, pp. 514-521. ISBN 80-7042-788-4.

14. KORTHAGEN, F. A. J. - WUBBELS, T. Characteristics of Reflective Practitioners: Towards an Operationalization of the Concept of Reflection. Teachers and Teaching: Theory and Practice 1995, nr. 1/1, pp. 51-72. ISSN 1354-0602.

15. KYRIACOU, CH. Essentials Teaching Skills, Oxford 1991: Blackwell, pp. 150. ISBN 0-631-17647-0.

16. LAMBERT, D. - BALDERSTOUNE, D. Learning to Teach Geography in the Seconary School. A Comanion to School Experience. RoutledgeFlammer, London and New York 2000, 474 pp. ISBN 0-415-15676-0.

17. LAMBERT, D. Curriculum Corruption? On the Place of Subjects in Secondary School Curriculum Making. GW Unterricht 110/2008, Wien, pp. 7-13. ISSN 20771517.

18. MAGUIRE, S. - GUYER, C. Preparing Geography, Earth and Environmental Science Students for Employment in the Enterprises Culture. Journal of geography in Higher Education, 25/2004, nr. 1. pp. 121-126. ISSN 1466-1845.

19. MISZCZUK, R. Ocena przygotowania zawodowego nauczycieli w świetle badań autobiograficznych - analiza porównawcza. In Piekarski J., Tomaszewska L., Szymańska M. (eds.): Pedagogika tom 6. Ksztatcenie pedagogów - strategie, koncepcje, idee „Nauczyciel - zawód czy powołanie“. Część 
I Konteksty pedeutologiczne. Zeszyty Naukowe PWSZ, Płock 2007, p. 43. ISSN 1641-9839.

20. OSIŃSKI, Z. Kompetencje miękkie absolwenta humanistycznych studiów wyższych a metody prowadzenia zajęć. In Sitarska B., Droba R., Jankowski K. (eds.): Studia wyższe z perspektywy rynku pracy. Wydawnictwo Akademii Podlaskiej, Siedlce 2010, pp. 57-66. ISBN 978-83-7051-583-6.

21. OSUCH, W. Kompetencje nauczycieli geografii oraz studentów geografii - kandydatów na nauczycieli. Prace Monograficzne nr 570. Wydawnictwo Uniwersytetu Pedagogicznego w Krakowie, Kraków 2010, pp. 304. ISBN 978-83-7271-620-0, ISSN 0239-6025.

22. OSUCH W. Kompetencje w zakresie komunikacji interpersonalnej w dobie postępujących procesów globalizacji [In:] Przedsiębiorczość w warunkach globalizacji (eds. Z. Zioło, T. Rachwat). Przedsiębiorczość - Edukacja Nr 7. Warszawa-Kraków 2011, pp. 333-346. ISBN 978-83-267-0333-1.

23. OWEN, E. What Skills Do Employers Need? Journal of Geography in Higher Education, 25/2001, nr. 1, pp. 121-126. ISSN 1466-1845.

24. PERRY, R. Teoria i praktyka (trans. by B. Mazur). Proces stawania się nauczycielem. WSiP SA Warszawa 2000, p. 105. ISBN 83-02-07780-1.

25. PIRÓG, D. Studia wyższe a rynek pracy w Polsce - zarys stanu badań. In Sitarska B., Droba R., Jankowski R. (eds.): Studia wyższe z perspektywy rynku pracy. Wydawnictwo Akademii Podlaskiej, Siedlce 2010, pp. 67-80. ISBN 978-83-7051-583-6.

26. PISKORZ, S. Rola i zadania polskiego nauczyciela geografii na przełomie XX i XXI wieku. In Jarowiecki J., Piskorz S. (eds.) Różne drogi kształcenia i doksztatcania nauczycieli geografii (eds.): J. Jarowiecki, S. Piskorz. Materiały na konferencję naukową Kraków 23-24. 4. 1996. pp. 144-152.

27. PISKORZ, S. (ed.) Zarys dydaktyki geografii, Wydawnictwo Naukowe PWN, Warszawa 1997, Wyd II, 238 pp. ISBN 83-01-12353-2.

28. PRŮCHA J. Pedeutologia. In Śliwerski B. (ed.) Pedagogika. Pedagogika wobec edukacji, polityki oświatowej i badań naukowych. Tom 2, Gdańskie Wydawnictwo Pedagogiczne, Gdańsk 2006, pp. 293-316. ISBN 83-7489-022-3.

29. VIELHABER, CH. Wie viel Nachhaltigkeit verträgt das Schulfach Geographie und Wirtschaftskunde? GW Unterricht 103/2006, Wien, pp. 17-24. ISSN 20771517.

30. VIELHABER, CH. Standards und/oder kompetenzen im GW-Unterricht? GW Unterricht 110/2008, Wien, pp. 1-6. ISSN 20771517. 
31. WAHLA, A. Vnější podněty geografického vzdělávání. In Zioło Z. (ed.): Znaczenie geografii w systemie edukacyjnym. Problemy Studiów Nauczycielskich nr 25. Wydawnictwo Naukowe Akademii Pedagogicznej, Kraków 2000, pp. 97-102. ISSN 0239-6769.

32. ŻEGNAŁEK, K. Studia trzystopniowe - za i przeciw. In Sitarska B., Droba R., Jankowski K. (eds.): Studia trzystopniowe a jakość kształcenia w szkole wyższej. Wydawnictwo Akademii Podlaskiej, Siedlce 2007, pp. 155-160. ISBN 978-83-7051-433-4.

\section{Contact}

Wiktor Osuch

Pedagogical University of Cracow

Institute of Geography

Department of Geography Education

Cracow

Poland

e-mail: wiktor_osuch@wp.pl wikosuch@ap.krakow.pl 